\title{
CYCLIC ADENOSINE 3':5'-MONOPHOSPHATE AND PROTEIN KINASE LEVELS IN DEVELOPING BOVINE SPERMATOZOA
}

\author{
D. D. HOSKINS, D. T. STEPHENS AND M. L. HALL \\ Reproductive Physiology Section, Oregon Regional Primate Research Center, \\ 505 N.W. 185th Avenue, Beaverton, Oregon 97005, U.S.A.
}

(Received 24th September 1973)

The presence of both cyclic $3^{\prime}: 5^{\prime}$-adenosine monophosphate (cAMP) and the enzymes required for its synthesis, degradation, arıd apparent expression of action have been documented in mammalian spermatozoa. Several studies (Garbers, Lust, First \& Lardy, 1971; Garbers, First, Sullivan \& Lardy, 1971; Garbers, First, Gorman \& Lardy, 1973; Garbers, First \& Lardy, 1973a; Hoskins, 1973) have shown that motility can be induced or maintained by cyclic nucleotides and phosphodiesterase inhibitors in bovine spermatozoa from the cauda epididymidis and that increased rates of respiration and fructolysis occur concomitantly. Advantage was taken in these studies of the fact that the motility of bovine spermatozoa from the cauda epididymidis can be substantially reduced by simple incubation at $37^{\circ} \mathrm{C}$ in isotonic buffers over a relatively short period of time (several hours). Since bovine spermatozoa from the caput epididymidis resemble quiescent caudal cells in that they are characterized by a virtual absence of motility (Igboeli \& Foote, 1968) and low glycolytic rates (D. D. Hoskins, unpublished observations), the question arises as to whether the level of cAMP is a prime determinant in the epididymal development of the capacity for motility and increased metabolic rates. The same question can be asked about the cAMP-dependent protein kinases since these enzymes, present in large amounts in bovine spermatozoa from the cauda epididymidis (Hoskins, Casillas \& Stephens, 1972; Garbers et al., 1973b), have been implicated in the physiological expression of all actions of cAMP (Kuo \& Greengard, 1969a, b). In this communication, we report the levels of cAMP and cAMP-dependent and -independent protein kinases in bovine spermatozoa from the caput and cauda epididymidis.

Cyclic AMP was determined by the method of Gilman (1970) except that commercial bovine heart cAMP-dependent protein kinase (Sigma Chemical Co.) was used as the cAMP-binding protein. Assays were performed on spermatozoa from the epididymides of testes stored overnight at $4^{\circ} \mathrm{C}$. A prewarmed $\left(37^{\circ} \mathrm{C}\right)$ solution consisting of $42 \mathrm{~mm}-\mathrm{KCl}, 88 \mathrm{~mm}-\mathrm{NaCl}, 5 \mathrm{~mm}-\mathrm{MgSO}_{4}, 10$ mM- $\mathrm{KH}_{2} \mathrm{PO}_{4}$ and $10 \mathrm{~mm}$-tris, $\mathrm{pH} 7 \cdot 2$ was used to isolate, wash, and suspend the spermatozoa. Spermatozoa were obtained from the distal cauda epididymidis by the method of Henle \& Zittle (1942) and from the distal portion of the caput, after excess blood vessels had been trimmed away, by gently shaking the 
lacerated organ for $10 \mathrm{~min}$ at $37^{\circ} \mathrm{C}$ in the medium. Both cell types were washed three times and suspended to a concentration of 1 to $3 \times 10^{9}$ spermatozoa $/ \mathrm{ml}$. Suspensions of spermatozoa from the caput epididymidis were contaminated with 2 to $3 \%$ of erythrocytes. After sonic irradiation at maximum intensity for $1 \mathrm{~min}$ (Bronwill Biosonic III sonifier), both cell types were extracted for cAMP assay as described by Gilman (1970) for other bovine tissues. Conditions for washing and disrupting spermatozoa for determination of protein kinase activities have been described (Hoskins et al., 1972). Sperm counts were made in triplicate with a haemocytometer. Protein was measured by the method of Lowry, Rosebrough, Farr \& Randall (1951).

The levels of cAMP and cAMP-dependent and -independent protein kinase activities in bovine spermatozoa from the caput and cauda epididymidis are shown in Table 1. Spermatozoa from the cauda epididymidis contain significantly $(P<0.01)$ greater amounts of cyclic nucleotide and cAMP-independent

Table 1. Cyclic AMP content and protein kinase activity of bovine spermatozoa from the caput and cauda epididymidis

\begin{tabular}{|c|c|c|c|}
\hline \multirow{2}{*}{$\begin{array}{l}\text { Epididymal } \\
\text { region }\end{array}$} & \multirow{2}{*}{$\begin{array}{c}\text { cAMP content } \\
\left(\text { pmol } / 10^{9} \text { sperm. }\right)\end{array}$} & \multicolumn{2}{|c|}{$\begin{array}{c}\text { Protein kinase activity } \\
\left(\text { units }^{*} / 10^{8} \text { sperm. }\right)\end{array}$} \\
\hline & & $c A M P$-independent & $c A M P$-dependent $\dagger$ \\
\hline $\begin{array}{l}\text { Caput } \\
\text { Cauda }\end{array}$ & $\begin{array}{l}153 \pm 16 \\
214 \pm 15 \ddagger\end{array}$ & $\begin{array}{l}192 \pm 22 \\
298 \pm 22 \$\end{array}$ & $\begin{array}{l}817 \pm 34 \\
924 \pm 54\end{array}$ \\
\hline
\end{tabular}

Values are expressed as Means \pm S.E.M.

* One unit equals pmol ${ }^{32} \mathrm{P}$ incorporated from $\left[{ }^{32} \mathrm{P}\right] \mathrm{ATP}$ in $5 \mathrm{~min}$ at $30^{\circ} \mathrm{C}$ and pH 6.0 in 50 mm-sodium acetate buffer.

$\dagger$ cAMP-dependent activity represents the difference between $\left[{ }^{32} \mathrm{P}\right] \mathrm{ATP}$ incorporation in the presence and absence of $1 \mu \mathrm{M}$ cAMP.

$¥$ Different from spermatozoa from the caput epididymidis, $P<0.01,44$ d.f., Student's $t$ test (two-tailed distribution).

$\S$ Different from spermatozoa from the caput epididymidis $P<0.01,8$ d.f.

protein kinase $(P<0.01)$ than spermatozoa from the caput. Both cell types contain comparable amounts of cAMP-dependent protein kinase. Consideration of the absolute amount of cAMP present in each cell type and subsequently carried over into the assay system, however, is essential to an understanding of the difference noted in cAMP-independent activity between cell types. This difference may be an artifact in that more cAMP is carried over from spermatozoa from the cauda than from the caput. An increase in the amount of endogenous cAMP in this protein kinase assay system would be expected to effect a greater dissociation of protein kinase into catalytic and regulatory subunits (Garbers et al., 1973b). On the basis of the number of spermatozoa of each type subjected to sonication, the intracellular concentrations of cAMP, and the magnitude of the required dilutions before measurement of kinase activity, it can be calculated that the amount of cAMP carried over would result in 3.8 and $5.3 \mu \mathrm{m}$ solutions of cyclic nucleotide for caput and cauda cells respectively. These values are approximately $20 \%$ of the $\mathrm{K}_{\mathrm{m}}$ value (25 nM) for cAMP for purified bovine sperm protein kinase (Hoskins et al., 1972). Hence, any cAMP change in this range would significantly affect catalytic rates. 
The absolute increase in cAMP during epididymal transit, $60 \mathrm{pmol} / 10^{9}$ spermatozoa, is equal to or greater than the increase shown by Garbers $e t$ al. (1973a) to be sufficient to induce or maintain motility in submotile bovine spermatozoa from the cauda epididymidis. Despite many attempts, however, we have not been able to induce significant motility in spermatozoa from the caput epididymidis with either $\mathrm{N}^{6}, \mathrm{O}^{2}$-dibutyryl adenosine $3^{\prime}: 5^{\prime}$-monophosphate or theophylline. In a typical experiment, incubation $\left(45 \mathrm{~min}, 5 \times 10^{8}\right.$ spermatozoa/ml) with $4 \mathrm{~mm}$-dibutyryl cAMP or $5 \mathrm{~mm}$-theophylline in the diluent described earlier in this paper resulted in only the faintest suggestion of an increase in motility. The number of spermatozoa from the caput epididymidis showing any movement, when observed at $37^{\circ} \mathrm{C}$ in a haemocytometer, increased from less than $1 \%$ to slightly more than $2 \%$. In recent experiments, motility has been induced in as many as $20 \%$ of caput spermatoza with either $10 \mathrm{~mm}$ caffeine or theophylline. At $23^{\circ} \mathrm{C}$, motility is initiated within $2 \mathrm{~min}$, it peaks at 10 to $12 \mathrm{~min}$ and is essentially lost by $45 \mathrm{~min}$.

We conclude from this study that the increase in cAMP levels, but not protein kinase activity, in developing bovine epididymal spermatozoa is of sufficient magnitude to be one determinant in the development of the capacity for increased motility and metabolism.

This study was supported by Grant HD-05969 from the United States Public Health Service. Publication No. 678 from the Oregon Regional Primate Research Center, Beaverton, Oregon, 97005.

\section{REFERENGES}

Garbers, D. L., First, N. L., Gorman, S. K. \& Lardy, H. A. (1973) The effects of cyclic nucleotide phosphodiesterase inhibitors on ejaculated porcine spermatozoan metabolism and fertility. Biol. Reprod. 5, 599.

Garbers, D. L., First, N. L. \& Lardy, H. A. (1973a) The stimulation of bovine epididymal sperm metabolism by cyclic nucleotide phosphodiesterase inhibitors. Biol. Reprod. $5,589$.

Garbers, D. L., First, N. L. \& Lardy, H. A. (1973b) Properties of adenosine 3', $5^{\prime}$-monophosphatedependent protein kinases isolated from bovine epididymal spermatozoa. F. biol. Chem. 248, 875.

Garbers, D. L., First, N. L., Sullivan, J. J. \& Lardy, H. A. (1971) Stimulation and maintenance of ejaculated bovine spermatozoan respiration and motility by caffeine. Biol. Reprod. 5, 336.

Garbers, D. L., Lust, W. D., First, N. L. \& Lardy, H. A. (1971) Effects of phosphodiesterase inhibitors and cyclic nucleotides on sperm respiration and motility. Biochemistry, 10, 1825.

Gilman, A. G. (1970) A protein binding assay for adenosine $3^{\prime}, 5^{\prime}$-cyclic monophosphate. Proc. natn. Acad. Sci. U.S.A. 67, 305.

Hente, G. \& Zittle, G. A. (1942) Studies of metabolism of bovine epididymal spermatozoa. Am. $\mathcal{F}$. Physiol. 136, 70.

Hoskins, D. D. (1973) Adenine nucleotide-mediation of fructolysis and motility in bovine epididymal spermatozoa. $\mathcal{F}$. biol. Chem. 248, 1135.

Hoskins, D. D., Gasillas, E. R. \& Stephens, D. T. (1972) Gyclic AMP-dependent protein kinases of bovine epididymal spermatozoa. Biochem. biophys. Res. Commun. 48, 1331.

Igboel, G. \& Foote, R. H. (1968) Maturation changes in bull epididymal spermatozoa. J. Dairy Sci. $51,1705$.

Kuo, J. F. \& Greengard, P. (1969a) An adenosine 3',5'-monophosphate-dependent protein kinase from Escherichia coli. F. biol. Chem. 244, 3417.

Kuo, J. F. \& Greengard, P. (1969b) Cyclic nucleotide-dependent protein kinases. IV. Widespread occurrence of adenosine $3^{\prime}, 5^{\prime}$-monophosphate-dependent protein kinase in various tissues and phyla of the animal kingdom. Proc. natn. Acad. Sci. U.S.A. 64, 1349.

Lowry, O. H., Rosebrough, N. J., Farr, A. L. \& Randall, R. J. (1951) Protein measurement with the Folin phenol reagent. $\mathcal{F}$. biol. Chem. 193, 265. 